\title{
Comparative infection of autologous primary T cells and monocytes derived DCs using cell-free virus preparation, viral biofilm, pseudotyped-virus or viral synapse
}

\author{
Sandrine Alais, Hélène Dutartre ${ }^{\dagger}$, Renaud Mahieux ${ }^{*+}$ \\ From 16th International Conference on Human Retroviruses: HTLV and Related Viruses \\ Montreal, Canada. 26-30 June 2013
}

HTLV-1 infected T cells and blood dentritic cells (DCs) can be found in HTLV-1 carriers. It is currently believed that $\mathrm{T}$ cell infection requires cell-cell contact, while DCs could also be infected with cell-free virus. However, a comparative study using different modes of viral preparation for infecting human primary autologous $\mathrm{T}$ and $\mathrm{DC}$ cells has not been performed. Supernatant from HTLV-1 chronically infected $\mathrm{T}$ cells, cell conjugates between HTLV-1 infected cells and target cells, or purified viral biofilm were used side-by-side to infect autologous human primary lymphocytes and monocytes-derived dendritic cells. To monitor the early steps of viral infection, we also used pseudotyped viruses carrying either the HTLV-1 or the VSV envelopes. Infection was then followed by flow cytometry, ELISA, immunofluorescence, real-time PCR and alu-PCR. Our first data show that, depending on the source of viruses, lymphocytes have distinct susceptibility to HTLV-1 infection. The impact of the viral source in the spread of HTLV-1 infection will be discussed.

Submit your next manuscript to BioMed Central and take full advantage of:

- Convenient online submission

- Thorough peer review

- No space constraints or color figure charges

- Immediate publication on acceptance

- Inclusion in PubMed, CAS, Scopus and Google Scholar

- Research which is freely available for redistribution

Submit your manuscript at www.biomedcentral.com/submit

* Correspondence: renaud.mahieux@ens-lyon.fr

Oncogenèse Rétrovirale, label « Lique Nationale Contre le Cancer », CIR , Labex Ecofect, INSERM U1111-CNRS UMR5308, Université Lyon-1, Ecole Normale Supérieure, Lyon, Cedex 07, France 